Religare, ISSN: 19826605, v.16, n.2, dezembro de 2019, p.615-635

\title{
Profetismo, religião e sociedade no Antigo Israel: formas de organização e conflitos
}

\author{
Prophecy, religion and society in Old Israel: forms of \\ organization and conflicts
}

Thiago da Silva Pacheco ${ }^{1}$

\section{Resumo}

Buscamos analisar o status de profeta na sociedade do Antigo Israel a partir dos textos do Primeiro Testamento. Considerando os estudos sobre o tema, que identificam aquelas figuras como visionários, adivinhos, milagreiros e proclamadores de palavras divinas, pretendemos demonstrar que as figuras independentes, proponentes de transformações sociais e religiosas, estavam envolvidas numa disputa de forças contra as figuras ligadas ao templo ou ao rei. Esta disputa levou o profetismo a ser regulado e limitado, no período Babilônico, pelos escribas e sacerdotes, por meio da Lei Mosaica.

Palavras-chave: Profetas; Antigo Israel; Primeiro Testamento.

\section{Abstract}

We seek to analyze the status of prophet in Old Israel society from the texts of the First Testament. Considering the studies on the subject, which identify those figures as visionaries, soothsayers, miracle workers and proclaimers of divine words, we intend to demonstrate that the independent figures, proponents of social and religious transformations, were involved in a dispute of forces against the figures linked to the temple or to the king. This dispute led prophetism to be regulated and limited in the Babylonian period by scribes and priests through the Mosaic Law.

Keywords: Prophets; Old Israel; First Testament.

\footnotetext{
${ }^{1}$ Doutor em História Comparada pela Universidade Federal do Rio de Janeiro (PPGHC-UFRJ). Especialista em Ciências da Religião pela Faculdade do Mosteiro de São Beto. Professor de História de Israel e Teologia do Antigo Testamento na FATUN-Kennedy. E-mail: pacheco.tsp@gmail.com
} 
Religare, ISSN: 19826605, v.16, n.2, dezembro de 2019, p.615-635

\section{Introdução}

Como pudemos argumentar noutra oportunidade (PACHECO, 2014, p. 46), o fenômeno da profecia, na forma de homens ou mulheres como transmissores das mensagens dos deuses, não era estranho nas culturas do Antigo Oriente Próximo, entre as quais se inclui a israelita. Figuras oraculares eram comuns entre fenícios, mesopotâmios, hititas e egípcios (LINDBLOM, 1973; LIMA, 2012; CARVALHO, 2003).

Entre os israelitas, o status de profeta foi atribuído a vários dos personagens do Primeiro Testamento, como Abraão (Gn 20:7) e Moisés (Dt 34:10). No Livro dos Juízes narra-se um profeta anônimo que vem falar a Gideão sobre a missão de libertar Israel do domínio estrangeiro, além do papel de Débora como líder tribal'2. No Livro de Samuel há uma série de menções a profetas (1 Sm. 3:20, 9:9-19, 10:16, 15:35, 16:10, 18:10), sendo o personagem que empresta o nome ao livro não apenas importantíssimo à trama, como também uma espécie de mestre (1 Sm. 19.20). Elias e Eliseu são descritos em posição de destaque nos Livros dos Reis. E a estes exemplos se somam os livros proféticos - Isaias, Jeremias, Ezequiel, Amós e Miquéias, entre outros - cujos oráculos são atribuídos aos personagens que nomeiam tais obras (PACHECO, 2014, p. 46).

Neste sentido, ainda que todos os textos citados sejam posteriores aos momentos que se propõem a narrar, a figura do profeta era bem conhecida entre os hebreus, até porque, como já mencionamos, o fenômeno do profetismo era amplamente conhecido no espaço e tempo em que se desenvolveu a sociedade israelita na antiguidade (PACHECO, 2014, p. 46), com especial semelhança aos textos proféticos neoassírios e de Mari (LIMA, 2012, p. 40-41). Para Max Weber, estes personagens eram heróis carismáticos e solitários, militando uma luta ética a favor do Javismo. Afirmou Weber:

\footnotetext{
2 Embora possa parecer surpreendente, indica uma flexibilidade e permissividade quanto ao papel social das mulheres no Israel tribal e pré-monárquico (SMITH, 2006, p. 51). Ver também Pacheco (2014, p.46).
} 
Religare, ISSN: 19826605, v.16, n.2, dezembro de 2019, p.615-635

As experiências sagradas destes profetas são, portanto, absolutamente individuais; nem eles, nem seus auditórios, pensam que elas eram suscitadas pela influência emocional da massa. (...) É somente após ter sido interpelado pela voz encarnada de Javé que o próprio profeta adquire a certeza de ser o instrumento de Deus invisível. Ele invoca a revelação para fundar sua legitimidade e não a natureza sagrada da experiência extática. Assim, os profetas não se rodeiam de uma comunidade que teria praticado êxtase coletivo ou que teria suscitado revelações extáticas como vias de salvação. Não se encontra o menor traço disso na profecia javista clássica. (WEBER, 1970, p. 390-391)

Por outro lado, algumas passagens bíblicas, sob o olhar de pesquisas mais recentes como as de Lindblom (1973, p. 65-83) e Mercedes García Bachmann (2013, p. 171-174), sugerem a existência de uma organização profética na forma de círculos iniciáticos, como vemos nas narrativas referentes a Samuel (1 Sm. 10:12; 19: 19-24;), a Elias e a Eliseu (2 Rs. 2) (PACHECO, 2014). Ordens de profetas também faziam parte de conselhos régios, sendo consultadas em tempos de crise ou dúvida (LIVERANI, 2008, p. 155-156). Ademais, há, nos textos do Primeiro Testamento, diferentes formas de classificação acerca destas figuras com dons oraculares, onde pelo menos cinco títulos se relacionam com a atividade de consulta e recepção de respostas divinas: nabi, hozeh, ro'eh, qosem e elohim, sendo cada um deles referente a um tipo de prática e status religioso (LIMA, 2012, p. $57-64)$.

Considerando que a multiplicidade de práticas religiosas ligadas ao profetismo também estabelecia múltiplas condições sociais na antiga sociedade israelita, percebemos que aquelas figuras nem sempre se relacionavam de forma harmoniosa entre si, fosse com as elites, fosse com as classes sacerdotais instituídas. Neste sentido, procuramos situar estes diferentes status em relação

\footnotetext{
3 Segundo Weber "[...] o carisma profético designa, antes de tudo, a atitude de compreender racionalmente os desígnios de Javé, ele supõe igualmente qualidades absolutamente diferentes e irracionais, tal como um poder mágico [...] Os profetas não reivindicam nada mais do que o conhecimento dos desígnios e do poder miraculoso de Deus. Este não empreende nada, afirma Amós, sem referi-lo previamente a seus profetas. Tal é a origem do sentimento que eles têm de seu valor. Numa certa medida, os profetas reivindicam igualmente o poder de influenciar as decisões de Javé." (WEBER, 1970, p. 394-395).
} 
Religare, ISSN: 19826605, v.16, n.2, dezembro de 2019, p.615-635

as suas formas de organização social no Antigo Israel a partir das identificações mencionadas no parágrafo anterior, considerando as concorrências referentes ao trabalho religioso produzido pelos profetas tanto como agentes da religião estabelecida quanto como agentes contestatórios desta mesma religião (BOURDIEU, 2007, p. 57-69). Tal disputa, pretendemos demonstrar, acarretou a tentativa de controle do profetismo por parte de escribas e sacerdotes, através da Lei Mosaica, a partir do Exílio Babilônico.

\section{As diferentes classificações}

Comecemos abordando as classificações relacionadas ao fenômeno do profetismo em Israel. Primeiramente o termo hozeh, cujo significado, segundo Lima (2012, p. 61-62), seria “olhar, contemplar, presenciar, ver". Isto pode expressar o sentido de "visionário" - sempre utilizado no masculino - e refere-se a indivíduos que recebiam revelações através da visão e/ou audição. Nestes casos, a revelação recebida era mais importante que o processo pelo qual se dava tal experiência com o sagrado - contemplar uma visão extraordinária, ouvir a palavra da divindade ou ambos (PACHECO, 2014, p. 47).

O termo ro'eh, cujo significado é "vidente", deriva do verbo $r a^{\prime} a h$, que significa "ver". Expressa revelações divinas recebidas através de visões, normalmente ligadas ao êxtase religioso (LIMA, 2012, p. 62-63). A nomeação do profeta como vidente em Amós (Am 7.12) é também um dado importante, na medida em que a primeira versão deste livro data do século VIII a.C. com atualizações no século VII a.C. (SICRE, 1998, p. 189-191), contendo alguns dos relatos mais antigos disponíveis. Isto nos remete ao texto de $1 \mathrm{Sm}$ 9: 8,9, no qual é dito que em tempos antigos o profeta era conhecido como vidente (PACHECO, 2014, p. 47).

De fato, nas tradições mais antigas do Reino do Norte, seria Saul, e não Samuel, o filho de Ana, como seu nome se presta melhor ao jogo de palavras na oração daquela personagem (RÖMER, 2008, p.97). Saul teria buscado orientação 
Religare, ISSN: 19826605, v.16, n.2, dezembro de 2019, p.615-635

de um vidente "ro'eh" anônimo antes de tornar-se rei, enquanto a figura de Samuel, como profeta e sacerdote em Siló, tratar-se-ia de uma construção posterior (KAEFER, 2016, p. 410-411).

Neste sentido, as classificações hozeh e ro'eh, usadas em tempos mais antigos, foram paulatinamente substituídas e inseridas na classificação de nabi, cujo significado seria algo próximo de "nomear, chamar". O termo pode ser entendido ativamente, com sentido de "aquele que chama, que fala", "arauto", ou passivamente, no sentido de "chamado", sendo o segundo caso aparentemente mais verossímil. $\mathrm{O}$ verbo $n b^{\prime}$, que expressa a atividade profética, é usado de várias formas, relacionando-se à experiência de êxtase, discursos morais, consultas à divindade e realização de milagres. Segundo Lima (2012, p. 57-60), o termo é aplicado para figuras masculinas e femininas, tanto individualmente quanto para grupos - como as guildas ligadas ao êxtase religioso ou membros das classes de profetas do culto ou da corte - e pode, também, designar de forma generalizada os personagens tidos como mensageiros divinos na história passada de Israel (PACHECO, 2014, p.47;54).

Este termo - nabi - indicava um receptor e transmissor humano da revelação divina enquanto "Palavra de Deus", preponderância que explicaria a mudança de nomenclatura de 1 Sm 9:9 (LIMA, 2012, p. 66). Assim, personagens outrora conhecidos como videntes foram posteriormente chamados de nabi, termo que se tornou honorífico e passou também a classificar ancestrais importantes como Abraão (Gn 20:7), e os profetas escritores do passado, os quais, como abordaremos mais adiante, nem sempre ostentaram o título de nabi em seu tempo.

O termo elohim - Homem de Deus - é outro título honorífico, que, aplicado a um profeta, realçava a proximidade com Deus enquanto Seu mensageiro, bem como a capacidade de realizar milagres. É sempre aplicado na forma masculina, porém nunca aplicado nos livros proféticos (LIMA, 2012, p. 63-64).

Por fim, o termo qosem expressa o ato de adivinhar - ou predizer, pressagiar. Representa, portanto, os indivíduos conhecedores de métodos de 
Religare, ISSN: 19826605, v.16, n.2, dezembro de 2019, p.615-635

vaticínio a fim de descobrir segredos e obter respostas por parte da divindade. Estes métodos são classificados de duas formas por José Luís Sicre (1998, p. 3660) e Maria de Lourdes Lima (2012, p. 11-12): indutivos - “técnicas bem determinadas para ter acesso à divindade" - ou intuitivos - "a expectativa de manifestação de seres pertencentes ao mundo divino ou ao além". Nesse sentido, entre os métodos indutivos estavam observação da natureza (utilizada por Davi em 2 Sm 5.24 e tratada ironicamente em Isaias 47.13), observação dos animais, observação a partir dos sacrifícios (do qual a mãe de Sansão se valeu em Jz 13.1923), observação de alguns líquidos (como a água) ou mediante instrumentos como taças (utilizado por José, Gn 44.5), flechas (aplicado por Eliseu em 2 Rs 13.14-19), bastões (condenado por Oséias em 4.12) e dados ou pedras marcadas (Js 7.17,18; 1 Sm 10.19,21). Já os métodos intuitivos envolviam interpretação de sonhos (Gn 20.3; 28.11-16; 37; 40; 41; 1 Rs 3, 5 entre outros), consulta aos mortos (condenada em Dt 18.9-11, Is 8.19 e no relato de Saul em 1 Sm 28) e comunicação de oráculos divinos, sendo este o mais importante do ponto de vista bíblico.

Algumas destas figuras estavam diretamente ligadas aos cultos espalhados pelos santuários, templos e altares em Israel e Judá. Atuavam junto aos sacerdotes em seus ofícios sagrados, conforme descrito em Is 28:7; Jr 2:8,26 e Mq 3:11 (LIMA, 2012, p.66). Embora sejam classificados de forma distinta nos textos bíblicos, dependiam das instituições sacerdotais para exercerem sua vocação. Nestes casos incluiam-se os qosem, que também faziam parte destes corpos sacerdotais (Jr. 27:9,10; 28:8,9; Is 3:2,3; Mq 3: 6,7). Assim, os profetas da corte e os adivinhos compunham o corpo de funcionários de instituições religiosas, no sentido tipológico sacerdotal que Weber (2000, p. 294-295) propõe.

Além dos profetas ligados aos santuários, havia também grupos profeticos nos palácios (1 Sm 22.5; 2 Sm 7.2,3; 12.25; 24.11; 1Rs 1:8-15; 32-34, 38, 44-45). Eram servos do rei, que viviam à sua sombra e dependiam de sua generosidade e favores, "comendo da mesa do rei", ou seja, sendo mantidos pela autoridade dos monarcas. Isto aparece bem ilustrado na passagem de Amós 7:10-13, onde o o sacerdote de Betel, que servia diretamente ao rei, diz que em Judá o profeta 
Religare, ISSN: 19826605, v.16, n.2, dezembro de 2019, p.615-635 poderia "comer pão e profetizar", ou seja, exercer o ofício profético de forma "profissional", porém noutro lugar que não ali - afinal, Amós pregava contra o rei. (LIMA, 2012, p. 66).

Em síntese, os termos usados para identificar alguns profetas, como hozeh e ro'eh, foram aplicados em tempos mais antigos, posteriormente substituídos e englobados pelo termo nabi, cujo significado passou a incluir os visionários e videntes do passado. Já o termo qosem, como veremos mais adiante, desapareceu aos poucos, tornando tanto a figura do adivinhador quanto a prática da adivinhação condenáveis pelo judaísmo e, mais tarde, pelo cristianismo.

\section{Mulheres profetisas}

O status de nabi era naturalmente percebido e concedido ao gênero feminino nos textos do Primeiro Testamento. Hulda (2 Rs 22: 14-20), esposa de um funcionário real em Jerusalém, é uma profetisa importante para a narrativa deuteronomista (RÖMER, 2008, p. 56-57). O texto não revela se Hulda também era funcionária do Palácio Real, apenas que seu marido era "guarda das vestiduras". De qualquer forma, isto seria verossímil, já que mulheres eram encontradas em várias funções no serviço ao rei (BACHMANN, 2013, p. 104-106).

Outra menção a uma mulher profetisa, mais significativa, é a de Débora (Jz 4 e 5), não apenas pela narrativa mais detalhada, mas também pelo seu papel como líder, inclusive no campo de batalha. Segundo os textos, ela atuou ao lado de um comandante chamado Baraque, sendo consultada numa região onde havia uma palmeira que recebeu seu nome em homenagem (Jz 4.4-9). Devemos salientar, contudo, que narrativa dos Juízes - na qual Débora é descrita - em sua estrutura cíclica é construção posterior a partir de relatos lendários sobre heróis do reino do Norte (RÖMER, 2008, p. 94; 137). Neste sentido, o fato da memória de uma heroína profetisa ser preservada expressa que mulheres no papel de vaticinadoras carismáticas não eram algo estranho aos hebreus (SMITH, 2006, p. $48-51)$. 
Religare, ISSN: 19826605, v.16, n.2, dezembro de 2019, p.615-635

Além disso, práticas mágicas também estavam presentes entre algumas profetisas do período monárquico. O livro de Ezequiel expressa dura crítica aos encantamentos utilizados por elas, nos quais faziam travesseiros e véus para "caçar" e "prender" almas em troca de pagamento (Ez. 13: 17-21). Eliade (1992, p. 108) classifica este tipo de prática como "magia dos nós", onde se tecem laços mágicos capazes de controlar o bem ou o mal sobre alguém. A polêmica contra aquelas profetisas-feiticeiras demonstra, assim, que a magia dos véus e travesseiros era comum e conhecida.

Observa-se desta forma que, apesar dos poucos dados oferecidos pelas Escrituras, parece claro, pelos relatos de Hulda, Débora e das profetisas "encantadoras", que o carisma profético era encontrado e aceito também entre as mulheres na sociedade do Israel antigo, pelo menos até o fim do período monárquico. O título de profetisa é atribuído a estas personagens sem nenhuma inibição (LIMA, 2012, p. 60-61), e a mesma naturalidade é percebida quando Isaias refere-se a uma delas (Is 8:3). A crítica do livro de Ezequiel também não se direciona ao fato de mulheres serem profetisas, mas por profetizarem "de seu coração" - ou seja, não eram as palavras da divindade, mas delas mesmas - e para as práticas de um nocivo feitiço de aprisionamento de almas.

Contudo, infelizmente não é possível saber, a partir da narrativa bíblica, como as profetisas se organizavam em torno de seu carisma, se é que o faziam. Mercedes García Bachmann argumenta a favor da participação feminina nas guildas de profetas - que abordaremos mais adiante -, baseada nos relatos das esposas daqueles personagens (2Rs. 2), e até mesmo de guildas exclusivas de mulheres profetisas, devido ao relato de Ezequiel 13 (BACHMANN, 2013, p. 171174). Entretanto, estas afirmações carecem de bases mais firmes de sustentação, 
Religare, ISSN: 19826605, v.16, n.2, dezembro de 2019, p.615-635

posto que os textos não deixam claro nenhum tipo de organização específica acerca destas mulheres ${ }^{4}$.

\section{Organizações Proféticas}

De qualquer forma, o status derivado do carisma divino estava na base da formação de grupos compostos por homens que desfrutavam daquela honraria. Lembramos que, em alguns casos, o termo nabi referia-se a grupos de profetas extáticos (LIMA, 2012, p. 59). A este tipo de organização social, Max Weber (1982, p. 218) chama de estamento que, ao contrário das classes - que são movidas por motivos econômicos - erguem-se em torno de uma honraria da qual seus membros - no caso, os profetas bíblicos - compartilham (PACHECO, 2014, p.50).

Por definição, a honra estamental se faz visível através de um modo de vida especifico por parte de seus membros (WEBER, 1982, p. 218). No período monárquico do Antigo Israel, este modo de vida era perceptível no que J. Lindblom (1973, p. 65-83) classifica como guildas de profetas. As narrativas em torno de Samuel, Elias e Eliseu indicam corporações organizadas em torno de um mestre, o qual desfrutava de grande autoridade. Em alguns casos, este mestre e seus discipulos - chamados de filhos de profeta - viviam e comiam juntos em habitações simples (2 Rs 4:38), e às vezes andavam em bandos, cantando e dançando em êxtase. Os iniciados eram chamados de filhos dos profetas, numa forma de analogia paterna da relação mestre-aprendiz, e podemos notá-la, por exemplo, quando um homem da multidão que via Saul profetizando questiona quem seria o pai daqueles profetas que ali estavam (1 Sm 10.12). De fato, Eliseu chama Elias de "meu pai", exclamando ao vê-lo desaparecer (2 Rs 2.12) e é emblemático que ele tenha pedido porção dobrada do espírito de seu mestre antes dele partir (2 Rs 2.9), na medida em que esta porção é a herança que cabia ao filho primogênito (Dt 21.17). (PACHECO, 2014, p. 51).

\footnotetext{
${ }^{4}$ Num sentido mais amplo, esta dificuldade se estende para o estudo da mulher como um todo neste corpo documental. Para uma discussão introdutória quanto a este problema, ver BACHMANN, (2013, p. 17-23).
} 
Religare, ISSN: 19826605, v.16, n.2, dezembro de 2019, p.615-635

O "pai", portanto, era o mestre que liderava a guilda, enquanto os filhos eram seus discípulos, submetidos à disciplina e práticas místicas. Este mestre iniciava a seus "filhos" em técnicas de indução ao êxtase, e os noviços apresentavam marcas distintas, entre elas roupas peculiares, como o traje de peles de Elias (2 Rs 1.8). Os iniciados também eram marcados corporalmente, em formas de estigmas, como na história narrada em 1 Rs 20.35-41, que apresenta um filho de profeta marcado com uma ferida pelo seu companheiro. Ao revelar aquela ferida ao rei, o monarca imediatamente foi capaz de identifica-lo como "um dos profetas" (v. 41). Da mesma forma, o termo escrever com a mão a Javé em Is 44.5 pode ser interpretado com uma marca na mão do profeta, o que concordaria diretamente com Zc 13.4-6, apontando para uma época na qual os profetas iniciados com aquelas marcas não mais deveriam existir (PACHECO, 2014, p. 51-52).

A organização destas corporações parece ter sido relativamente livre, permitindo aos profetas casarem-se, terem filhos e até mesmo possuirem suas próprias moradias (2 Rs cap. 4). Respeitados como homens santos, eram procurados devido a seus poderes oraculares tanto por pessoas comuns como pelos membros mais abastados da sociedade do Israel Antigo: homens ricos, anciões, reis e rainhas (LINDBLOM, 1973, p. 70, 71). Em alguns casos, recebiam algum tipo de pagamento pelos seus vaticínios (1 Rs 14:3), mas o relato de Eliseu, Gezaí e Naamã, onde a oferta do homem curado fora recusada pelo profeta, pode indicar excessões a esta regra (2 Rs 5:15-23).

Por outro lado, estes dados se apresentam claramente quando falamos das guildas do norte, de alguma forma relacionadas com Elias e Eliseu. Não é possível saber até que ponto os profetas da corte e dos santuários mantinham organização semelhante. Mas a julgar pela profecia de Zc. 13.4-6, em contexto pós-exílico, que menciona a vestimenta do manto de pelos e as marcas de iniciação nas mãos, é possível que estas fossem práticas gerais dos nabi, não apenas dos grupos independentes de Elias e Eliseu. 
Religare, ISSN: 19826605, v.16, n.2, dezembro de 2019, p.615-635

\section{O profetismo independente e as criticas às instituições proféticas}

Até aqui analizamos como os profetas inseriam-se na sociedade do Israel Antigo, fosse em guildas independentes, fosse como parte do culto, fosse como funcionários do rei. Porém, nem todos os profetas estavam ligados a estes grupos, havendo aqueles que vivenciaram sua vocação de forma individual (LIMA, 2012, p. 73-76), como é o caso já citado de Amós. Seu status e lugar social, portanto, não dependiam de nenhuma instituição, ao contrário dos videntes, visionários e adivinhos que faziam parte do corpo sacerdotal ou que eram servos do rei, alvos de críticas severas por parte dos profetas independentes.

Foi a partir século VIII a.C. que começaram a ser registradas estas críticas. Segundo seu livro homônimo, Amós faz questão de dizer que "não (era) profeta nem filho de profeta" (Am 7:14), em resposta à ordem do sacerdote de Betel de que fosse para o Reino do Sul e lá profetizasse. Isto indicava que Amós não estaria envolvido nem compromissado com os grupos de profetas sob controle dos sacerdotes e dos príncipes que oprimiam as classes menos abastadas de Israel: neste sentido, Amós se pronunciava contra esta elite, que calava os profetas, impedindo-os de proferirem a vontade de Javé (Am 2:12).

Visão semelhante se vê no livro de Miquéias, mais ácido e revoltoso em sua militância contra o sistema constituído em Judá, também no século VIII a.C (SICRE, 1990, p. 337-422). Neste texto, os profetas surgiam, de uma forma geral, mancomunados com os notáveis e sacerdotes do povo, inclusive vaticinando por mero interesse (Mq 3.11). Para Miqueias, os profetas não apenas abriram mão da luta contra opressão a partir dos designios de Javé, como também aproveitavamse de seu status para obter vantagens ${ }^{5}$.

\footnotetext{
${ }^{5}$ Max Weber já chamava a atenção para esta postura da gratuidade da profecia, principalmente em Amós, mas também em outros livros proféticos: é a não profisionalização do profeta que o diferenciaria dos adivinhos, curandeiros, mágicos e até dos sacerdotes: “[...] um princípio fundamental era comum a todos os profetas enquanto grupo social, era a gratuidade de seus oráculos. É por isso que eles se distinguiam dos profetas reais que eles criticavam, porque eles conduziam o país à sua perdição, e de todos estes profetas que tiravam benefício de sua ciência à maneira dos antigos videntes e curandeiros, gente desprezível que eles condenavam" (WEBER, 1970, p.372).
} 
Religare, ISSN: 19826605, v.16, n.2, dezembro de 2019, p.615-635

O livro de Isaias, por seu turno, expressa críticas mais comedidas quanto a estes grupos. Embora declare que existiam profetas que ensinavam a falsidade (9.15) e que tropeçavam devido a uma vida faustosa $(28.7,8)$, o personagem principal é descrito vestindo-se com a roupa de pelos típica dos iniciados em corporações de profetas (Is. 20.2; LINDBLOM, 1973, p. 65-67). A segunda geração de discipulos de Isaías, representada pelo corpo textual do Dêutero Isaías, chega a vaticinar um futuro onde a descendência de Israel estaria marcada na mão da mesma forma que eram marcados estes iniciados (Is 44:5).

Críticas como a de Miquéias, onde os profetas estão mancumunados com os sacerdotes e mentem acerca de suas premonições para obter dinheiro, são expressas também nos livros de Sofonias (3.4), Jeremias (5.31; 23: 9-17) e Ezequiel (13 e 22: 24-31). O primeiro personagem (mas não necessariamente o livro que leva seu nome) teria exercido seu ministério no século VII a.C., o segundo entre o final do século VII e início do século VI, e o terceiro durante o século VI. Ou seja, observa-se que a contestação aos profetas ligados aos templos e cortes, talvez iniciada por Amós e Miquéias, prosseguiu pelos séculos seguintes, chegando até o período pós-exílico, contexto a profecia atribuída a Zacarias vaticina uma época em que tais grupos não mais existiriam:

E acontecerá naquele dia que os profetas se envergonharão, cada um da sua visão, quando profetizarem; nem mais se vestirão de manto de pelos, para mentirem. Mas dirão: Não sou profeta, sou lavrador da terra; porque certo homem ensinou-me a guardar o gado desde a minha mocidade. E se alguém lhe disser: Que feridas são estas nas tuas mãos? Dirá ele: São feridas com que fui ferido em casa dos meus amigos (Zc. 13: 4-6).

Este trecho expressa um dos pensamentos vigentes no período pós-exílico, no qual o Templo e a cidade de Jerusalém tornaram-se o centro da vida religiosa dos judeus. Embora a passagem citada de Zacarias trate com zelo os grandes profetas do passado e suas mensagens de arrependimento (Zc. 1.4-6, 7.7,12, 8.9), a profecia não mais se faria necessária, porque o povo aprenderia a guardar a Lei 
Religare, ISSN: 19826605, v.16, n.2, dezembro de 2019, p.615-635

de Moisés e os cultos no templo. Ou seja, tratou-se de uma reação das elites sacerdotais, deslegitimando novas críticas proféticas ${ }^{6}$.

O profetismo independente era, portanto, contestatório. Segundo Weber (2000, p. 294-295), as figuras de tipo profético - em quaisquer segmentos religosos - amparam-se num carisma pessoal, que os cobre de legitimidade para contestar a ordem religiosa estabelecida e opor-se a figuras de tipo sacerdotal, que institucionalizam o carisma e elaboram doutrinas, práticas religiosas e tabus. Para Bourdieu (2007, p. 57-69), falamos de dois tipos de produção distinta, na forma de trabalho religioso, e antagônicas, posto que os sacerdotes são agentes da religião estabelecida enquanto as figuras proféticas propõem rupturas com a concepção religiosa estabelecida, sem depender de suas instituições como fonte de carisma.

Partindo desta tipologia proposta por Weber e Bourdieu, os videntes, visionários e profetas que compunham grupos de profissionais religiosos atuavam junto a sacerdotes e adivinhos, sendo funcionários da religião institucionalizada. Já a maior parte dos "profetas escritores" não faziam parte de nenhum grupo institucionalizado nem recebiam deles seu carisma. Alguns foram chamados de visionários, nos casos de Amós, Isaías, Miquéias, Abdias e Naum, enquanto outros foram sujeitos do verbo $n b$ - profetisar - no caso Jeremias, Ezequiel e Amós. Quanto a Oseias, Sofonias e Malaquias, nem os verbos, nem os títulos são aplicados a estes personagens (LIMA, 2012, p. 74-76). Apenas Habacuque ostentava o título de nabi, enquanto Zacarias e Ageu faziam parte de

\footnotetext{
${ }^{6}$ Max Weber identificou esta postura crítica acerca dos "profetas profissionais nos textos atribuídos aos profetas: "Em virtude de sua eleição, os profetas reivindicavam certas qualidades específicas. A expressão 'espírito de Javé' (ruah) só aparecia raramente; é unicamente antes do exílio, em Isaias (XXX, I), que ela designa uma qualidade especificamente profética, embora a expressão 'homem do espírito' (Os. IX, 7) se encontre por vezes num profeta escriturário. Só é a partir de Ezequiel, após no Deutero-Isaias e nos profetas pós-exílicos que o termo aparece frequentemente. Parece que a hostilidade dos antigos profetas em relação aos neviim profissionais os tinha levado a evitar este termo ou a utilizá-lo só raramente. A isto se acrescenta que, na linguagem ordinária, o termo ruah designava, essencialmente, o êxtase irracional e passageiro, enquanto que os profetas deviam o seu prestígio ao fato de que eles eram capazes a todo o momento de compreender lucidamente e de comunicar claramente as intenções de Javé" (1970, p. 394-395).
} 
Religare, ISSN: 19826605, v.16, n.2, dezembro de 2019, p.615-635 grupos proféticos ligados aos sacerdotes e ao templo: os demais "profetas escritores" receberam o título de nabi depois do tempo de sua pregação, num estágio avançado da redação de seus livros. Além da mensagem contestadora às elites da época, aquelas figuras polemizaram ou mesmo condenaram os grupos instituídos de profetas e vizionários que compunham a corte e os núcleos sacerdotais, como foi o caso de Amós (7:14,15), Isaías (28:7-12), Miquéias (3:57,11), Sofonias (3:4) e Jeremias (14:13-16; 23:9-32; 27:9-10, 14-8). Apesar de Zacarias expressar uma visão positiva (Zc. 1:4-6; 7:7), ainda assim, como já mencionamos, vaticinou o fim dos profetas (Zc. 13:1-6).

Quando este processo se iniciou? No século IX a.C., durante o reinado de Acabe, já vemos a atuação contestatória de Elias e Eliseu contra o culto a Baal, praticado pela família real e amplamente difundido na sociedade israelita. Aqui temos o confronto entre os sacerdotes e profetas baalitas contra a profecia javista, perseguida e tratada como subversiva por Acabe, de acordo com os textos bíblicos. As narrativas e interpretações posteriores - ou seja, a versão que temos nos livros dos Reis - trataram este confronto como uma disputa entre o monoteísmo e politeísmo, entre a religião original dos israelitas e uma abominação estrangeira. Entretanto, tratou-se originalmente da disputa entre os profetas de Javé e de Baal pela influência política na corte, pois os reis consultavam seus oráculos em decisões de Estado. Enquanto Javé era a divindade nacional de Israel, Baal era o deus da poderosa rainha e de vários reinos estrangeiros, com quem Israel estabelecia importantes relações internacionais e comerciais (LIVERANI, 2008, p. 147; 158-160).

Porém, no Antigo Oriente Próximo, era comum a correlação entre divindades chamada de "translatibilidade", onde deuses com características semelhantes eram equiparados a deuses de nações vizinhas. Neste caso, Baal e Javé eram tidos como deuses das tempestades (SMITH, 2006, p. 166-167), ainda que este aspecto estivesse diluído no caso de Javé7. Acabe possivelmente aceitava

\footnotetext{
${ }_{7}$ Sobre os diferentes aspectos de Javé e a construção do monoteísmo a partir dele, ver o outro trabalho de Smith (2001).
} 
Religare, ISSN: 19826605, v.16, n.2, dezembro de 2019, p.615-635

a translatibilidade com Baal - que inclusive já era adorado, entre outros deuses, pelos os camponeses israelitas, sem precisar ser "importado" (LIVERANI, 2008, p. 159) - identificando o deus nacional Javé com a versão fenícia daquela divindade em favor das relações internacionais vantajosas para a monarquia e para as elites. O conflito entre profetas de Javé e profetas de Baal se deu, portanto, devido a perda de poder político daqueles junto ao rei, em favor de novos atores políticos baalitas, e também devido a perspectivas nacionalistas e regionais por parte dos javistas, contra o internacionalismo proposto pelas alianças monárquicas.

Esta disputa foi resolvida de forma violentíssima, com Eliseu aliando-se à Síria para patrocinar um golpe de Estado por parte do general Jeú, guerreiro javista cujo movimento de ascenção foi assustadoramente radical (LIVERANI, 2008, p. 148-149) e levou a normas severas de separação religiosa (CRUZEMAN, 2001, p. 204). A historiografia deuteronomista, iniciada durante o reinado de Josias, revisitou estas disputas numa perspectiva nacionalista, unificadora e de culto exclusivamente javista, como se fosse um embate henoteísta e nacional contra inovações politeístas e estranhas à identidiade do povo (LIVERANI, 2008, p. 158-160; RÖMER, 2008, p.155).

Mas a dinastia javista inaugurada por Jeú não duraria para sempre, e, de qualquer forma, o texto de 2 Rs 10 termina denunciando que Jeú “[...] não teve cuidado de andar com todo o seu coração na lei do Senhor Deus de Israel, nem se apartou dos pecados de Jeroboão, com que fez pecar a Israel." (2 Rs 10:31). Não nos parece ser possível compreender se Jeú rendeu-se às nescessidades do comércio internacional, como Acabe, ou se a sentença de 2 Rs 10 era apenas uma construção posterior a fim de encaixar este monarca no esquema deuteronomista de "reis bons e reis maus" (LOWERY, 2004; RÖMER, 2008). Mas o fato é que a permissão ao culto a Baal e outras divindades, populares dentro e fora de Israel antes e depois de Jeú, retornou. Aliado a atroz exploração econômica por meio de sistemas de impostos e empréstimos que empobrecia os camponeses em favor 
Religare, ISSN: 19826605, v.16, n.2, dezembro de 2019, p.615-635 de uma elite estatal e citadina (LIVERANI, 2008, p. 199-2048) - elite da qual faziam parte os profetas e visionários que serviam aos reis e aos sacerdotes - a crítica profética subsequente, iniciada em Amós, insistiu na questão das transformações sociais, legitimando-as como ordenanças de Javé, enquanto Oséias denunciou o que considerava serem violações ao culto javista, comparando-as com prostituição (SMITH, 2006, p.92, 93).

Tal foi a situação de Israel, ao norte. Em Judá, os profetas da corte de Davi, como Gad e Natan (2 Sm.7:2;12:25; 1 Rs 1:8-45; cf. LIMA, 2012, p. 58) atuavam num contexto no qual o culto nacional era mais dependente da figura do rei, Vigário de Javé, situação que foi posta em cheque nos momentos de maior abertura dos reis de Jerusalém frente ao imperialismo Assírio, de quem Judá tornou-se vassalo (LOWERY, 2004). A solidez do Javismo no reino do sul permitiu que desde muito cedo os profetas de Javé tivessem hegemonia no palácio junto ao rei. Porém, sob a sombra régia, sua atuação era mais discreta e controlada em comparação ao profetismo no norte, situação que permaneceu até a queda de Samaria em 722 a.C. (LIVERANI, 2008, p. 180-182 ). Ou seja, o profetismo do sul era atrelado ao sacerdócio, produzindo trabalho religioso referente à religião que legitimava a monarquia, com pouco espaço para rupturas e, consequencemente, para profetismo independente. Foi somente após a queda do Reino do Norte e a fuga de migrantes para o sul que aquela crítica, que mesclava Justiça Social e culto a Javé, se desenvolveu em Judá com Miqueias ${ }^{9}$ e com o Proto-Isaías (LIVERANI, 2008, p. 199-204).

E quanto aos qosem (adivinhos)? A atuação de adivinhos na vida religiosa dos antigos hebreus era algo normativo, a ponto de ser impossível estabelecer uma distinção social clara entre os qosem, os sacerdotes e profetas ligados à corte ou o templo (LIMA, 2012, p.64; 67). Os sacerdotes consultavam a divindade através de urim e tumim (Ex 28.30; Lv 8.8; Nm 27.21; Dt 33.8), ou do efod (Jz 8.26-

\footnotetext{
${ }^{8}$ Com relação as desigualdades sociais e seus desdobramentos no culto e na sociedade do antigo Reino de Judá, ver o trabalho de LOWERY (2004).

${ }_{9}^{9}$ Ainda que Miquéias possa ter iniciado seu ministério antes, por volta do ano 750 a.C.
} 
Religare, ISSN: 19826605, v.16, n.2, dezembro de 2019, p.615-635

27; Ex 28.6-14; 39.2-7; 1 Sm 2.18, 28; 23.6) usados para sortear respostas por parte da divindade. Portanto, estes métodos e instrumentos faziam parte das práticas israelitas. Por outro lado, nos textos cuja autoria é atribuída aos profetas clássicos (como Jeremias, Isaías e Miquéias), os adivinhos surgem sempre descritos de forma condenatória, por adivinharem falsamente ou em troca de dinheiro. Assim, o termo qosem foi desaparecendo aos poucos, devido às palavras reprovadoras dos profetas e pela posterior condenação de tais práticas (Dt 18: 10,11) a partir dos grupos deportados para a Babilônia e envolvidos com os escribas deuteronomistas (RÖMER, 2008, p. 130), que condenavam práticas de adivinhação, consulta aos mortos e encantamento.

\section{A Lei Mosaica e a repressão sobre o carisma profético}

Durante o Exílio Babilônico, as figuras proféticas ofereceram aos deportados uma explicação para a crise que atravessavam. As profecias vaticinavam um futuro utópico, centrado em Jerusalém como a Cidade-Templo - no caso de Ezequiel - ou de um acesso do dom da profecia disponível a todo povo - no caso do Dêutero Isaías (LIVERANI, 2008, p. 277-280; RÖMER, 2008, p. 113-117). Contudo, houve um contraponto com relação a esta importância do profetismo, como o carisma profético incomodava aos sacerdotes e escribas no Exílio. Enquanto os escribas propunham uma reflexão "histórica" do que teria levado Judá ao Exílio - a chamada "história deuteronomista" - e os sacerdotes defendiam o apego às tradições, os profetas previam um tempo utópico no qual todos teriam acesso a Deus, sem a necessidade de intermediários como os escribas ou sacerdotes (RÖMER, 2008, p. 113-116; p. 132-133), que procuravam firmar-se como os governantes do povo.

Escribas e sacerdotes, portanto, olhavam para o passado: a história - cuja interpretação estava sob controle dos escribas - e as tradições - sob controle dos sacerdotes. Os profetas, por outro lado, olhavam para um futuro sem intermediários entre os homens e Deus. Assim, a fim de exercer controle sobre o 
Religare, ISSN: 19826605, v.16, n.2, dezembro de 2019, p.615-635

fenômeno profético, a autoridade Mosaica foi operada no sentido de limitá-la. Em Dt 18: 9-22 temos uma série de prescrições acerca de práticas mágicas, divinatórias e necromânticas. É também neste trecho que Moisés apresenta-se como o profeta modelo ${ }^{10}$, sendo os demais profetas passíveis de serem punidos com a morte, caso fossem farsantes. E a maneira de distinguir se um profeta era verdadeiro ou falso, segundo Dt.18, seria simples: se a palavra não foi cumprida, era falsa. Isto na prática legitimava os livros de Amós, Oséias, Miquéias e Sofonias - além de partes de Jeremias - todos eles importantes para a ideologia deuteronomista por predizerem o colapso sobre os Reinos de Israel e Judá, tragédias que os deuteronomistas esforçavam-se para explicar em 1 e 2 Reis. Ou seja, profetas cujas previsões teriam se cumprido, mas convenientemente não mais estavam vivos para pregar. Neste sentido, a profecia válida seria a dos profetas já mortos, cujos textos estavam sob controle daqueles escribas (RÖMER, 2008, p. 132-133; LIMA, 2012, p. 24-25). Assim, a "profecia" se tornou algo a ser interpretado por homens sábios e escribas, o que permitia manter algum controle sobre o imprevisível - tanto psíquica quanto socialmente - carisma profético.

De fato, a profecia foi retroativamente encerrada em Moisés, já que “em Israel nunca mais surgiu um profeta como Moisés, a quem o Senhor conhecia face a face" (Dt 34:10). Ou seja, como nenhum profeta recebeu maiores e mais profundas revelações que Moisés, nenhuma profecia poderia contradizer os textos atribuídos a autoridade mosaica. Isto implicou em duas consequências: a primeira foi que, sendo os profetas "não só [...] fiéis cumpridores da Lei, mas seus defensores" (LIMA, 2012, p. 25), toda profecia, fosse ela oral ou escrita, estaria sob os limites da Lei Mosaica e deveria ser interpretada sob a luz da mesma justamente pelos escribas e sacerdotes. A segunda foi a diminuição da proeminência dos profetas no judaísmo em comparação ao que se dava antes do Exílio Babilônico.

10 "O Senhor teu Deus te levantará um profeta do meio de ti, de teus irmãos, como eu; a ele ouvireis" (Dt 18:15). 
Religare, ISSN: 19826605, v.16, n.2, dezembro de 2019, p.615-635

Contudo, o profetismo estava longe de morrer, apesar da tentativa de domesticação e da perda de importância das figuras proféticas. Como já colocado, havia a perspectiva de um futuro utópico, quando o dom da profecia estaria disponível a todos. Esta perspectiva se apresentava também na esperança do retorno de um grande profeta, que seria alguém como Moisés (Dt 18: 15-18) ou o próprio Elias (M1 3:23). Tal retorno seria o prenúncio e inicio do novo tempo em que o Espírito seria derramado sobre toda carne (Jl 2 e 3). Ademais, figuras proféticas continuaram a surgir, como o Terceiro-Isaías, Malaquias, Ageu e o próprio Zacarias, que vaticinou o fim dos profetas.

\section{Conclusão}

No antigo Israel havia uma pluralidade de status e práticas atribuídos a personagens chamados de profetas: o nabi ("chamado"), hozeh ("visionário"), ro'eh ("vidente"), qosem (adivinho) e o elohim ("Homem de Deus"). Mulheres recebiam o título de nabi como os homens, embora não seja possível saber como elas se organizavam em grupos institucionalizados, se é que isto aconteceu. Alguns visionários ou profetas, que atuavam de forma independente, entraram em choque com os sacerdotes e demais figuras oraculares, primeiramente devido a proeminência política do culto a Baal, depois, pelo uso do carisma profético a favor das elites e contra os oprimidos. Desta tensão surgiram os "profetas escritores", que, posteriormente, foram tratados de forma honrosa pelo título profético nabi.

Porta-vozes de revelações consideradas divinas, as várias figuras proféticas eram sustentáculos das elites israelitas ou contestadoras das mesmas. As figuras contestadoras foram fundamentais para a formação do judaísmo e do monoteísmo bíblico, cuja origem remonta ao Exílio Babilônico. Entretanto, o carisma independente de templos ou da capacidade de interpretação de Textos Sagrados dos escribas era perigoso, sendo colocado sob controle a partir deste contexto. A contestação dos profetas a favor do culto a Javé, fundamental para a 
Religare, ISSN: 19826605, v.16, n.2, dezembro de 2019, p.615-635

formação do judaísmo e para os escribas, deveria ficar restrita aos textos sagrados que estavam sob controle destes escribas, e as profecias de acesso universal ao dom oracular, lançadas para um distante futuro utópico. A profecia, assim, deveria estaria restrita aos Livros Sagrados. E os profetas, restritos a heróis da fé do passado: veneráveis, porém mortos e com seus ministérios encerrados.

\section{Referências}

BACHMANN, Mercedes L. García. Women at work in the Deuteronomistic history. International voices in biblical studies/Society of Biblical Literature: 2013. v. 4. BOURDIEU, Pierre. A economia das trocas simbólicas. São Paulo: Perspectiva, 2007. CARVALHO, Alexandre Galvão. Interação social, reciprocidade e profetismo no mundo antigo. Vitória da Conquista: Uesb, 2003.

CRÜZEMAN, Frank. A Torah: teologia e história social da lei do Antigo Testamento. Petrópolis: Vozes, 2001.

ELIADE, Mircea. O sagrado e o profano. São Paulo: Martins Fontes, 1992.

KAEFER, José Ademar. A procura de Saul: uma análise de Primeiro Samuel 9 -(12)14. Horizonte, Belo Horizonte, v. 14, n. 42, p. 402-426, abr.-jun. 2016. Disponível em: http://periodicos.pucminas.br/index.php/horizonte/article/view/P.2175-

5841.2016v14n42p402. Acesso em: 23 dez. 2019.

LIMA, Maria de Lourdes Corrêa. Mensageiros de Deus: profetas e profecias no Antigo Israel. Editora PUC-Rio: São Paulo: Reflexão, 2012.

LINDBLOM, Johannes. Prophecy in Ancient Israel. Philadelphia: Fortress, 1973.

LIVERANI, Mario. Para além da Bíblia: história antiga de Israel. São Paulo: Paulus, 2008.

LOWERY, Richard. Os reis reformadores: culto e sociedade no Judá do Primeiro Templo. São Paulo: Paulinas, 2004.

PACHECO, Thiago da Silva. Experiências e práticas sagradas dos profetas bíblicos. Revista Oracula, ano 10, n. 15, 2014. Disponível em: https://www.metodista.br/revistas/revistasmetodista/index.php/oracula/article/view/5755. Acesso em: 23 dez. 2019.

RÖMER, Thomas. A chamada história deuteronomista: introdução sociológica, histórica e literária. Petrópolis: Vozes, 2008.

SICRE, J. L. A Justiça Social nos Profetas. São Paulo: Paulinas, 1990.

Profetismo en Israel. Navarra: Verbo Divino, 1998.

SMITH, Mark. O memorial de Deus. História, memória e a experiência do divino no Antigo Israel. São Paulo: Paulus, 2006.

. The orignis of biblical monotheism: Israel's polytheistic background and the Ugaritic texts. Oxford University Press: 2001.

WEBER, Max. Judaïsme antique. Études de sociologie de la religion. Tome Troisième, Paris: Plon, 1970.

. Ensaios de sociologia. Rio de Janeiro: Guanabara, 1982. 
Religare, ISSN: 19826605, v.16, n.2, dezembro de 2019, p.615-635

Economia e sociedade. Fundamentos da sociologia compreensiva. Brasília: UnB, 2000. v. 1.

Recebido em 05-08-2019.

Aprovado em 23-12-2019. 